Carlos Víctor Hernández Ramírez 1,4

(D) 0000-0002-7675-6141

Soila Maribel Gaxiola Camacho ${ }^{*}$

(i) 0000-0002-5078-7636

Ignacio Osuna Ramírez ${ }^{2}$

(1) 0000-0002-4419-0710

Idalia Enríquez Verdugo 1

(1) 0000-0001-6205-6083

Nohemi Castro del Campo'

(iD) 0000-0001-5248-3719

Héctor Samuel López Moreno ${ }^{3}$

(D) 0000-0001-7391-205X

'Laboratorio de Parasitología, Facultad de Medicina Veterinaria y Zootecnia, Universidad Autónoma de Sinaloa,

Boulevard San Ángel s/n, fraccionamiento San Benito, Culiacán, Sinaloa, México.

2Unidad de Investigaciones en Salud Pública Facultad de Ciencias Químico Biológicas

de la Universidad Autónoma de Sinaloa,

Boulevard San Ángel s/n, fraccionamiento San

Benito, Culiacán, Sinaloa, México.

${ }^{3}$ Titular del Laboratorio de Inmunología Molecular

Facultad de Ciencias Químico Biológicas,

Universidad Autónoma de Sinaloa,

Boulevard San Ángel s/n, fraccionamiento San

Benito, Culiacán, Sinaloa, México.

${ }^{4}$ Servicios de Salud de Sinaloa,

Departamento de Prevención

y Control de Vectores y Zoonosis.

*Corresponding author:

Tel: (667) 7181650

Email address:

soilagaxiola2@gmail.com

mvzhernandez_sin@hotmail.com

Received: 2016-04-18 Accepted: 2017-05-05

Published: 2017-06-16

Additional information and declarations can be found on page 9

@C Copyright 2017 Carlos Víctor Hernández Ramirez et al. open access $\boldsymbol{\partial}$

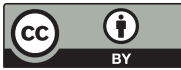

Distributed under Creative Commons CC-BY 4.0

\section{Prevalence and risk factors associated with serovars of Leptospira in dogs from Culiacan, Sinaloa}

\begin{abstract}
Domestic dogs transmit Leptospira spp. to humans, and determining the health risk that they represent is of paramount importance. To determine the seroprevalence and main risk factors associated with serovars of Leptospira in dogs from Culiacan, Sinaloa, we obtained serum samples from 165 dogs. The samples were stored at $-40{ }^{\circ} \mathrm{C}$ and were analysed by the microbiology laboratory at Centro Nacional de Sanidad Animal using the leptospirosis microscopic agglutination test. Additionally, a survey was performed to identify epidemiological risk factors, and statistical inference was determined using chi-square test, odd ratios, and logistic regression with a statistical significance set at $P<0.05$. The prevalence of Leptospira was $9 \%(15 / 165)$, and we identified seven serovars: canicola 17 (46\%), icterohaemorrhagiae (40 \%), bratislava (40 \%), grippotyphosa (33\%), shermani (33\%), pyrogenes (20\%) and ballum (13\%). Based on our epidemiological survey, the risk factors associated with the detection of antibodies against Leptospira include the permanent habitation of pets in courtyards $(O R=4.6, \mathrm{P}<0.05)$ and presence of water stored in drums and basins $(\mathrm{OR}=3.25, \mathrm{P}<0.05)$. The prevalence of leptospirosis in dogs indicates that the disease is present in the city of Culiacan and that leptospiral antibodies in dogs increase in poor sanitary conditions with stored water, which increases the potential risk of infection for both humans and animals.
\end{abstract}

Keywords: Leptospirosis, Leptospira, dog, prevalence, risk factors.

\section{Introduction}

Dogs are considered to be the most important domestic species that transmit Leptospira spp. to humans. ${ }^{1-6}$ In the state of Sinaloa, leptospirosis has been diagnosed in humans, ruminants and pigs. ${ }^{7}$ However, the extent of this disease

\section{Cite this as:}

Hernández Ramírez CV, Gaxiola Camacho SM, Osuna Ramirez I, Enríquez Verdugo I, Castro del Campo N, López Moreno HS. Prevalence and risk factors associated with serovars of Leptospira in dogs from Culiacan, Sinaloa. Veterinaria México OA 2017;4(2). doi: 10.21753/vmoa.4.2.369 
is unknown, as is the prevalence of Leptospira spp. serovars in dogs. Humans are susceptible to a large number of serovars of this bacterium, but the signs and symptoms of disease are not pathognomonic and can thus be easily confused with other infectious processes of bacterial or viral origin. ${ }^{8}$ Therefore, it is important to determine the seroprevalence of this disease and to identify the risk factors associated with various serovars of Leptospira in dogs in Culiacan, Sinaloa. This basic information could help in finding alternatives for disease control.

Leptospirosis is the most widespread zoonotic disease in the world and has great economic and health implications. In Mexico, it is an infectious disease of mandatory notification. The World Health Organization (WHO) and the Pan American Health Organization (PAHO) classify Leptospirosis icterohaemorrhagiae with the key A 27.0. ${ }^{9}$ The Official Mexican Standard NOM-029-SSA2-1999 provides the general procedures for monitoring cases of leptospirosis. ${ }^{8}$ This disease is caused by a pathogenic strain of a spirochete of the genus Leptospira and affects wild and domestic animals, as well as humans. It is traditionally classified based on its phenotypic properties, serological reactions and pathogenesis into $L$. biflexa and $L$. interrogans, sensu lato. The former is a group of mainly saprophytic species, while the latter is a group of pathogenic species. ${ }^{10}$ The current classification of the genus Leptospira is based on DNA homology and comprises 17 species. ${ }^{11-13}$

Leptospires are strictly aerobic microorganisms. Morphologically, they are spirochetes that are approximately $0.1 \mu \mathrm{m}$ wide and 6-15 $\mu \mathrm{m}$ long, with flexion, translation, and propulsion movements, as well as active ondulation. These bacteria are Gram-negative and divide by binary fission. Reservoir hosts may remain serologically positive for the disease for months or years. ${ }^{14-16}$ In dogs, leptospirosis is mainly caused by L. canicola or L. icterohaemorrhagiae. These serotypes are considered to be the most important serovars in certain regions.6,17 The main source of infection of animals, especially dogs, is the urine of asymptomatic carrier animals (dog to dog transmission), water, mud or contaminated fomites, as well as the natural reservoir of the bacteria, rodents. ${ }^{18,19}$ Leptospires infect an organism by penetrating through the mucous membranes, skin lacerations or skin softened by moisture or through intake of contaminated food and water. The bacterium then migrates through the blood, tending to localize and grow in parenchymal organs, such as the liver, kidney, spleen, and occasionally, the meninges. The bacterium remains in sites such as the renal tubules, ocular humors and uterus, where antibody activity is minimal. There, they cause vascular damage to the endothelium, which produces bleeding. ${ }^{17,20,21}$ The serovars icterohaemorrhagiae and pomona produce hemolysins, which are responsible for hemoglobinuria. ${ }^{22}$ The icteric type or severe hepato-nephritic (Weil's disease) occurs in approximately $10 \%$ of cases and is often related to infection with icterohaemorrhagiae, although it is not the only serovar that can produce such symptoms. However, most infections are anicteric.9,23 The serovar icterohaemorrhagiae causes severe jaundice in dogs, very similar to the infection caused in humans, 24,25 where changes in increases in body temperature usually go unnoticed. The onset of jaundice can be sudden or progressive, ranging from a pale yellow to an orange-yellow colour of the skin and mucous membranes, and other clinical signs include yellowish brownish urine, weakness, chills, depression, anorexia, emesis, polydipsia, emaciation, dehydration, petechial bleeding, ecchymosis of the conjunctiva and oral cavity, and halitosis. ${ }^{24-26}$ 
Leptospirosis is a zoonotic disease. Humans are susceptible to a large number of serovars of this bacterium. Person-to-person transmission is unusual, but several cases of congenital infection have been described. ${ }^{11}$ Furthermore, a case of transmission through breast milk has been described in the United States. ${ }^{27}$ In general, outbreaks in humans are caused by exposure to water contaminated with the urine of infected animals. ${ }^{28}$ In Mexico, serological studies have been carried out in dogs from various states of the country. Moles et al., 29 analysed serum from a total of 218 dogs from the Anti-Rabies Centre of Culhuacán in Mexico City and found that $28.44 \%$ were seropositive for one or more serovars. Leptospira canicola was the most prevalent, with $22 \%$ seropositivity. Flores and Solana 30 observed a seropositivity of $61.7 \%$ in all dogs studied. In the same year, Garcia and Ibarra ${ }^{31}$ found $41.5 \%$ seropositivity in dogs from Toluca in the State of Mexico. Luna 32 analysed serum from a total of 485 dogs from Naucalpan in the State of Mexico and found $48.4 \%$ seropositivity. The main source of infection for animals, and dogs in particular, is the urine of asymptomatic carrier animals, most importantly rodents, due to their capacity to act as a natural reservoir for the bacteria. ${ }^{33}$ In dogs, age, breed and gender are risk factors for leptospirosis, and so are environmental factors, such as increases in rainfall and temperature. ${ }^{18,34,35}$

Since the conditions in Sinaloa are like those of many other states in Mexi$\mathrm{Co}$, where the presence of seropositive dogs has been documented, we hypothesized that Sinaloa also has dogs with similar serovars and seroprevalence rates. To date the seroprevalence of this disease in dogs in Sinaloa has not been reported.

\section{Materials and methods}

This study was conducted in the city of Culiacan, Sinaloa, Mexico, located at $24^{\circ} 48^{\prime} \mathrm{N}$ and $107^{\circ} 23^{\prime} \mathrm{W}, 60$ meters above sea level. The climate of the region is classified as semi-dry, with a very warm average temperature of $25.5{ }^{\circ} \mathrm{C}$, with maximum temperatures of $45{ }^{\circ} \mathrm{C}$ in the months of July and August, minimum temperatures of $7{ }^{\circ} \mathrm{C}$ in December and January, and an annual rainfall of $671.14 \mathrm{~mm} .{ }^{36}$ These meteorological characteristics, and the frequent occurrence of extreme rainfall events (hurricanes) in Sinaloa ${ }^{37}$, create favourable conditions for outbreaks of leptospirosis.

The study was conducted during one year, from January to December. Study group and inclusion criteria: Dogs from Culiacan, Sinaloa were included in this study. According to the number of doses of rabies vaccine given during the last ten years, and according to the information from the dog census performed by the Sinaloa Health Services (SSA), it is estimated that there are approximately 44,000 dogs unvaccinated for leptospirosis in Culiacan, Sinaloa. In our study, we included dogs over three months old that received a rabies vaccination or participated in SSA's pet neutering program. Animals vaccinated against leptospirosis or with an ongoing disease were excluded from the analysis.

Before taking blood samples, we sent an epidemiological survey to the pet owners to obtain their address, as well as information on the conditions and characteristics of the places where the dogs lived. The questions were directly related to the epidemiological variables that are determining factors in the transmission 
of leptospirosis. We also asked for their authorization to take the blood samples. Blood samples $(3 \mathrm{ml})$ were obtained by venepuncture of the jugular vein. The blood was free of contamination and not hemolyzed, and the serum samples were frozen at $-40^{\circ} \mathrm{C}$. Once collected, the samples were analysed in the laboratory of the National Animal Health Centre in Tecamac, State of Mexico. Samples were processed using the Microscopic Agglutination Test (MAT). Commonly, the diagnosis of leptospirosis is performed by various methods including direct immunofluorescence, silver staining of fixed tissues, polymerase chain reaction (PCR), culture isolation, evidence of serum antibodies (ELISA), fast plate agglutination and latex agglutination, as well as rapid card tests (LEPTO dipstick). However, MAT is regarded as the gold standard technique, and it determines the presence of agglutinating antibodies against the tested serovars. 9,38 To perform MAT, the serum was initially diluted in saline solution (1:25), and each serum sample that showed an agglutination of at least $50 \%$ of the leptospires (compared to the control antigen) was considered positive. ${ }^{9}$ We used a panel that included the following serovars: ballum, canicola, hardjo, pomona, pyrogenes, icterohaemorrhagiae, bratislava, wolffii, australis, grippotyphosa, hebdomadis and shermani.

\section{Determination of sample size}

The sample size was determined using the formula for estimating proportions. ${ }^{39}$ Where:

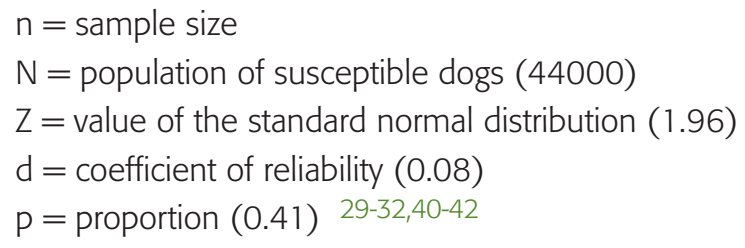

A total of 165 samples were taken in vacutainer tubes without anticoagulant; they were centrifuged for five minutes at $1008 \mathrm{~g}$ to obtain serum, which was then frozen. The cut-off points of the tests considered titers of 1:100 or greater as positive. $^{22,43}$ To identify risk factors, an epidemiological survey was sent to the owners of the dogs. In the survey we asked for the name of the owner, their address, number of dogs per owner, sex of these dogs, their breed, age, vaccination history, living environment, types of flooring, presence of rodents, water supply in the house, presence of pools or open water containers, presence of drainage, and number of residents per dwelling. We performed a transverse analytical study, and the answers to the questionnaire were quantified and the homogeneity of proportions was tested using the chi-square test $\left(\chi^{2}\right)$. The risks (OR, odds ratio) and confidence intervals were estimated using logistic regression. A value of $P<0.05$ was considered statistically significant. ${ }^{44,45}$

\section{Results and discussion}

We studied 165 serum samples of dogs from ninety-eight neighbourhoods in Culiacan, ranging medium (97\%) to high (3\%) socioeconomic status, and found 
fifteen positive titers. The descriptive analysis of the survey data indicated that the average number of pets per owner was 2.6 and that $82 \%$ of households had 1-3 dogs. Thus, it follows that dog owners usually have more than one pet. The age data indicated that most samples were taken from animals between one and two years old, corresponding to a percentage of $42.4 \%$, followed by animals under one-year-old (15.75\%), and finally by three-year-olds (14.54\%). Ward et al., 46 reported that animals between 4 and 6.9 years of age are at greater risk of contracting leptospirosis compared to animals under one year of age. Regarding the type of dog breed, we found that $66.7 \%$ of the serum samples were taken from mixed breed dogs, followed by small breeds, such as Poodles and Chihuahuas (20\%). These two groups made up $86.7 \%$ of the samples. Most sampled dogs were females (88.4\%) and only $11.6 \%$ were males. Ward et al., 35 reported that male dogs used for work and shepherding are at greater risk of contracting the disease.

The living environment of the dogs was also considered an important factor related to the epidemiology of leptospirosis; $87.15 \%$ of the dogs lived inside their owners' homes, while $15.07 \%$ of the sampled dogs had contact with the street outside their owners' yards. We observed that $6.6 \%$ of dogs remained exclusively inside the house, $38.74 \%$ lived inside and outside the house, and the majority (40.6\%) remained outside in the yard only. Regarding the flooring type, $41.2 \%$ of dogs lived on floors made of cement and $40 \%$ lived on floors made of both cement and dirt. The remainder lived only on dirt floors. With regards to the water supply in the homes, $97 \%$ had piped water and $11.5 \%$ reported using drums or basins for water storage. Drainage was present in $95.8 \%$ of households. Regarding the number of people living in each household, four residents per household was most common (33.07 \%), followed by households with five residents $(24.61 \%)$, and finally those with three residents (20\%). Rodents were reported in $47.7 \%$ of the households.

This serological study of 165 samples from dogs living in the city of Culiacan, Sinaloa, indicated a prevalence of Leptospira of $9 \%$. The serovars detected were: canicola, icterohaemorrhagiae, bratislava, grippotyphosa, shermani, pyrogenes and ballum. We also observed the presence of multiple serovars in a single host. It is possible that some animals with high titers $(1: 1600)$ were actually infected with the bacterium but did not yet show any clinical manifestations of disease (Table 1). The observed frequency for the serovars, from highest to lowest was as follows: canicola $46.6 \%$, icterohaemorrhagiae $40 \%$, bratislava $40 \%$, grippotyphosa $33.3 \%$, shermani $33.3 \%$, pyrogenes $20 \%$, ballum $13.3 \%$ (Figure 1).

L. canicola was the most frequently identified, with a $46.6 \%$ seropositivity, which is in agreement with Moles et al. ${ }^{29}$ These results are also consistent with those of other authors, who identified serovar icterohaemorrhagiae as the second most important serovar and associated it with rats as carriers and transmitters.

The epidemiological variables corresponding to living environment, number of pets per household, age, breed, water supply, drainage and presence of rodents, showed no significant relationships with regard to seroprevalence of Leptospira $(P>0.05)$. However, there was a significant difference between the pets that lived only outside and those that remained inside the house, and those that lived in the house but had access to the yard and the street $(\mathrm{OR}=4.6, \mathrm{P}=0.03$; Table 2). 
Table 1. Serovars of Leptospira identified in dogs.

\begin{tabular}{|c|c|c|}
\hline Sample number & Serovar & Titre \\
\hline \multirow[t]{3}{*}{9} & Grippotyphosa & $1: 200$ \\
\hline & Icterohaemorrhagiae & $1: 100$ \\
\hline & Bratislava & $1: 100$ \\
\hline \multirow[t]{3}{*}{12} & Grippotyphosa & $1: 600$ \\
\hline & Icterohaemorrahagie & $1: 600$ \\
\hline & Bratislava & $1: 800$ \\
\hline \multirow[t]{2}{*}{18} & Canicola & $1: 100$ \\
\hline & Shermani & $1: 100$ \\
\hline 20 & Bratislava & $1: 800$ \\
\hline \multirow[t]{2}{*}{21} & Grippotyphosa & $1: 200$ \\
\hline & Icterohaemorrhagiae & $1: 200$ \\
\hline 26 & Canicola & $1: 100$ \\
\hline 52 & Bratislava & $1: 800$ \\
\hline \multirow[t]{4}{*}{97} & Canicola & $1: 100$ \\
\hline & Pyrogenes & $1: 100$ \\
\hline & Grippotyphosa & $1: 200$ \\
\hline & Icterohaemorrhagiae & $1: 200$ \\
\hline 100 & Canicola & $1: 100$ \\
\hline \multirow[t]{2}{*}{142} & Grippotyphosa & $1: 200$ \\
\hline & Icterohaemorrhagiae & $1: 200$ \\
\hline 145 & Shermani & $1: 100$ \\
\hline \multirow[t]{2}{*}{151} & Canicola & $1: 200$ \\
\hline & Shermani & $1: 100$ \\
\hline \multirow[t]{2}{*}{161} & Icterohaemorragiae & $1: 200$ \\
\hline & Bratislava & $1: 200$ \\
\hline \multirow[t]{5}{*}{162} & Canicola & $1: 1600$ \\
\hline & Pyrogenes & $1: 800$ \\
\hline & Bratislava & $1: 200$ \\
\hline & Ballum & $1: 800$ \\
\hline & Shermani & $1: 1600$ \\
\hline \multirow[t]{4}{*}{171} & Canicola & $1: 800$ \\
\hline & Pyrogenes & $1: 400$ \\
\hline & Ballum & $1: 100$ \\
\hline & Shermani & $1: 200$ \\
\hline
\end{tabular}

Table 2. Place of habitation of pets

\begin{tabular}{|c|c|c|c|c|c|}
\hline Habitation & Negative & Positive & P-Value & OR & Confidence interval \\
\hline house/courtyard & 70.00 & 2.00 & & 1.0 & \\
\hline courtyard & 62.00 & 10.00 & 0.030 & 5.7 & $1.2-26.8$ \\
\hline street & 18.00 & 3.00 & 0.063 & 5.8 & $0.9-37.6$ \\
\hline Total & 150.00 & & 15.000 & & \\
\hline
\end{tabular}

Chi-square of likelihood ratio $=7.0 ; \mathrm{df}=2 ; \mathrm{P}=0.030$ 


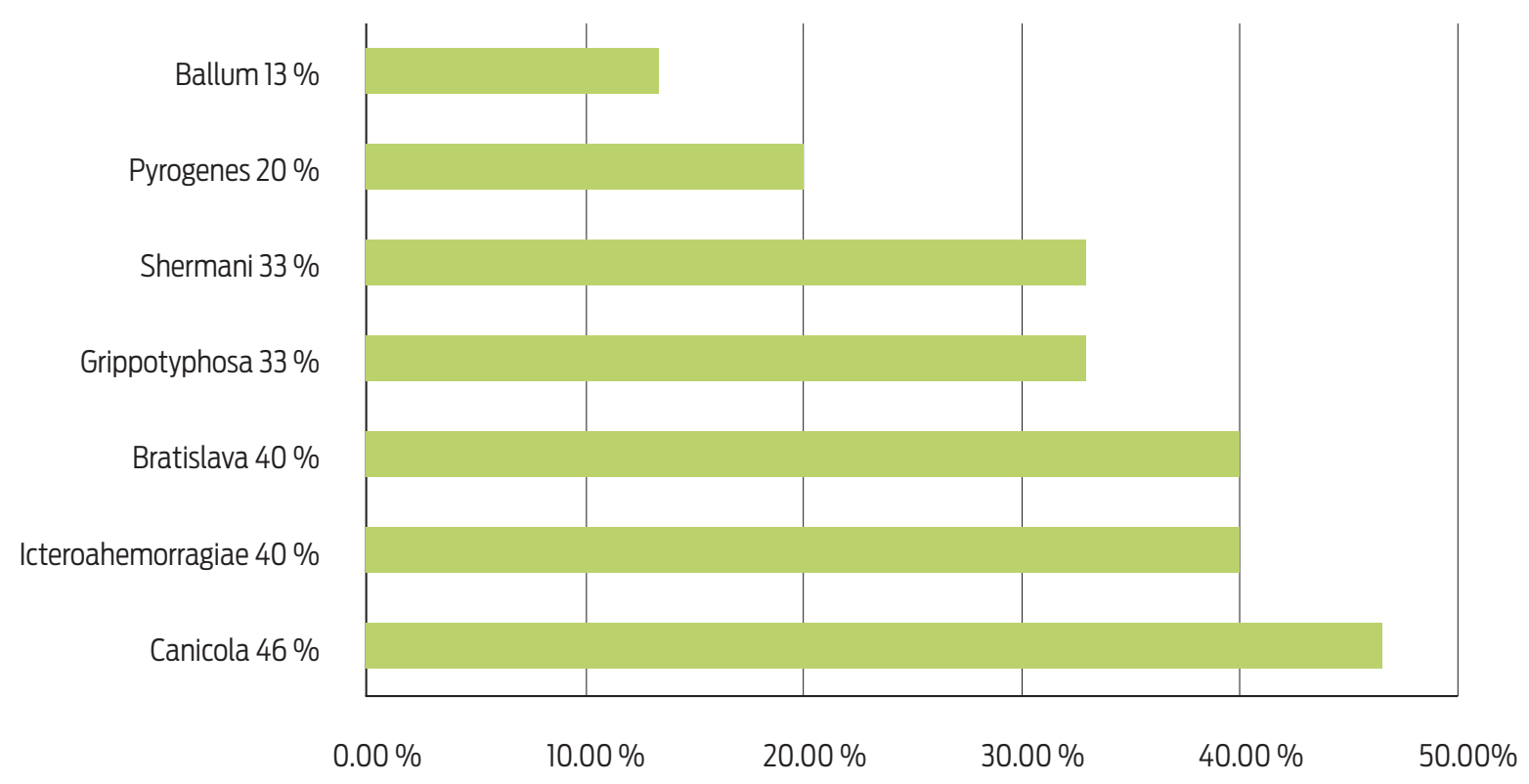

Figure 1. Frequency of observed serovars of Leptospira

The presence of water stored in drums and basins in the yard was significantly related to the seroprevalence of Leptospira. The mismanagement of water provides ideal conditions for the survival of bacteria in the household environment $(\mathrm{OR}=3.25, \mathrm{P}=0.03$; Table 3 ). The type of flooring in the areas inhabited by the pets was marginally significant $(P=0.06)$. Those that stayed on dirt and cement floors were the most affected. We postulate that the accumulation of water on this type of flooring may favour the development of infection (Table 4).

There was a significant difference in the seroprevalence of Leptospira found in dogs of different sexes (Table 5). The 15 positive samples were distributed evenly among the different neighbourhoods, which had similar characteristics in terms of the quality of the housing construction, access routes and socioeconomic level. Positive animals did not show clinical signs of the disease and their owners did not report having observed any evidence of illness. The vaccines conventionally used in veterinary clinics in Culiacan usually include four serotypes: canicola, grippotyphosa, icterohaemorrhagiae and pomona. Serovar pomona was not detected in this study. The serovars bratislava, pyrogenes, shermani and ballum, which were found in dogs in this study and are pathogenic to humans, are not included in common canine vaccines, creating a potential risk of infection for the pets. 47,48

Of the 15 positive samples, five (33.3\%) contained one serovar and ten contained two or more serovars (66.6 \%). Studies conducted in Mexico report up to five serovars detected in different regions, in contrast with the seven serovars found in this study. ${ }^{49}$ Two positive samples contained up to five different serovars each. The prevalence observed in this study ( $9 \%$ ) is lower than that reported for Mexico by several other authors because their studies were conducted using animals suspected of having clinical leptospirosis or at high risk for leptospirosis, including stray dogs, animals in veterinary clinics and rabies centres, and dogs in close contact with domestic animals, such as cattle, pigs, goats and sheep. ${ }^{40,42}$ By contrast, this study used samples from 'healthy' dogs. However, the prevalence found in this study is 
Table 3. Presence of drums and basins

\begin{tabular}{|c|c|c|c|}
\hline Drums/Basins & Frequency & Positive & Total \\
\hline yes & 20.00 & 5.00 & 25 \\
\hline no & 130.00 & 10.00 & 140 \\
\hline Total & 150.00 & 15.00 & 165 \\
\hline$\%$ & 90.91 & 9.09 & 100 \\
\hline
\end{tabular}

Chi-square of likelihood ratio $=3.46 ; \mathrm{df}=1 ; \mathrm{P}=0.063$

$\mathrm{OR}=3.25, \mathrm{Cl} 95 \%$ : 1.01-10.50

Table 4. Type of floor of the place inhabited by the pets

\begin{tabular}{|c|c|c|c|}
\hline & Negative & Positive & Total \\
\hline Dirt-Cement & 61.00 & 9.00 & 70 \\
\hline dirt & 26.00 & 4.00 & 30 \\
\hline cement & 63.00 & 2.00 & 65 \\
\hline Total & 150.00 & 15.00 & 165 \\
\hline$\%$ & 90.91 & 9.09 & 100 \\
\hline
\end{tabular}

Chi-square of likelihood ratio $=5.39 ; \mathrm{df}=2 ; \mathrm{P}=0.067$

Table 5. Sex of pets.

\begin{tabular}{|c|c|c|c|}
\hline Sex & Negative & Positive & Total \\
\hline female & 131.00 & 15.00 & 146 \\
\hline male & 19.00 & 0.00 & 19 \\
\hline Total & 150.00 & 15.00 & 165 \\
\hline$\%$ & 90.91 & 9.09 & 100 \\
\hline
\end{tabular}

Chi-square of likelihood ratio $=3.86 ; \mathrm{df}=1 ; \mathrm{P}=0.049$

close to that reported by Gautam et al. ${ }^{50}$ in a similar study conducted in the United States that included dogs in veterinary clinics. The serovars identified vary from region to region. Davis et al. ${ }^{51}$ observed a predominance of the serovars autumnalis, icterohaemorrhagiae and canicola in healthy dogs in the state of Washington, with a seroprevalence of $17 \%$. We found no specific studies to compare the other variables that were found to be significant in this study, such as keeping pets in yards $(O R=4.6, P<0.05)$. The presence of water stored in drums and basins was statistically significant compared to households without standing water $(O R=3.25$, $P<0.05)$. The presence of standing water favoured the possibility of spills and puddles of water, which provide ideal conditions for the survival of leptospires. 52,53 The sex of pets was also statistically significant $\left(\chi^{2}=3.8, P=0.049\right)$, with females having a higher prevalence compared to males. Positive female dogs in this study were in contact with 56 people who may be at risk of transmission of Leptospira from their pets. 


\section{Conclusions}

We identified dogs that were seropositive for Leptospira spp. in Culiacan, Sinaloa. Seropositivity was associated with risk factors in their environment include the permanent habitation of pets in courtyards $(\mathrm{OR}=4.6, \mathrm{P}<0.05)$ and presence of water stored in drums and basins $(O R=3.25, P<0.05)$. These animals can eliminate the bacteria through their urine and led to the possibility of transmission to other animals and humans.

\section{Funding}

Self-financing.

\section{Acknowledgements}

The authors thank to Laboratorio de Parasitología de la Facultad de Medicina Veterinaria y Zootecnia de la Universidad Autónoma de Sinaloa, to Unidad de Investigación en Salud Publica de la Facultad de Ciencias Químico Biológicas de la Universidad Autónoma de Sinaloa, and Servicios de Salud de Sinaloa del Departamento de Prevención y control de Vectores y Zoonosis.

\section{Conflicts of interest}

The authors declare that they have no conflicts of interest.

\section{Author contributions}

Carlos Víctor Hernández Ramírez. Investigation design, wrote the manuscript. Gaxiola Soila Maribel Camacho. Conducted the investigation.

Osuna Ignacio Ramírez. Analyzed data, wrote manuscript. Idalia Enríquez Verdugo. Wrote the manuscript, investigation design. Naomi Castro del Campo. Analyzed data, wrote manuscript. Samuel López Moreno. Wrote manuscript.

\section{References}

1. Gilllespie JH, Timoney JF. Hagan y Bruner: enfermedades infecciosas de los animales domésticos con especial referencia a : etiología, patogenia, inmunidad, epidemiología, diagnóstico y terapéutica biológica. 4 ed. DF (MX): La Prensa Médica Mexicana; 1983.

2. Blood DC, Henderson JA, Radostis OM. Medicina veterinaria. 5 ed. DF (MX): Interamericana; 1983.

3. Duque BM, Moreno MJ, Gómez D. Leptospirosis en edad pediátrica. DF (MX): Infectología Práctica; 1988.

4. Venkataraman KS, Nedunchelliyan S. Epidemiology of an outbreak of leptospirosis in man and dog. Comp Inmun Microbiol Dis. 1992;15(4):243-7.

5. Luna AMA, editor Aspectos clínicos reportados en leptospirosis canina. Primer Seminario Taller Nacional sobre el diagnóstico y control de la leptospirosis; 1997 23-25July; México: DF (MX).

6. Brod CS, Aleixo JA, Jouglard SD, Fernandes CP, Teixeira JL, Dellagostin OA. Evidence of dog as a reservoir for human leptospirosis: a serovar isolation, molecular characterization and its use in a serological survey canine lep- 
tospirosis. Rev Soc Bras Med Trop. 2005;38(4):294-300. doi: 10.1590/ S0037-86822005000400003.

7. Luna AM, Moles CL, Gavaldón RD, Nava VC, Salazar GF. Estudio retrospectivo de seroprevalencia de leptospirosis bovina en México, considerando las regiones ecológicas. Rev Cubana Med Trop. 2005;51(1):28-31.

8. Secretaría de Salud, Sagarpa, IMSS, UNAM, UAM, UADY. NOM-029-SSA2-1999, para la vigilancia epidemiológica, prevención y control de la leptospirosis en el humano. DF (MX): Diario Oficial de la Federación; 2001.

9. Organización Mundial de la Salud (OMS). Leptospirosis humana: guía para el diagnóstico, vigilancia y control / Organización Mundial de la Salud; traducción del Centro Panamericano de Fiebre Aftosa. Rio de Janeiro (BR): OMS; 2008.

10. Céspedes M. Leptospirosis: enfermedad zoonótica reemergente. Rev Peru Med Exp Salud Publica. 2005;22(4):290-307.

11. Faine S. Leptospirosis. Bacterial infections of humans. 2 ed. New York (US): Brachman, Plenum Medical Book; 1991.

12. Bharti AR, Nally JE, Ricaldi JN, Matthias MA, Diaz MM, Lovett MA, et al. Leptospirosis: a zoonotic disease of global importance. Lancet Infect Dis. 2003;3(12):75771. doi: 10.1016/S1473-3099(03)00830-2.

13. Brenner DJ, Kaufmann AF, Sulzer KR, Steigerwalt AG, Rogers FC, Weyant RS. Further determination of DNA relatedness between serogroups and serovars in the family Leptospiraceae with a proposal for Leptospira alexanderi sp. nov. and four new leptospira genomospecies. Int J Syst Bacteriol. 1999;49(2):839-58.

14. Caballero A. Leptospirosis canina y su relación con el hombre. XXII Congreso Internacional de la Asociación de Microbiología Clínica 1997. p. 86.

15. Sepúlveda MA, Dimas JS, Preciado RFJ. La rata y el perro importantes vectores de la leptospirosis en explotaciones pecuarias de Cd. Guzmán, Jalisco. Rev Cubana Med Trop. 2002;54(1):21-3.

16. Chapola EG, dos Santos MG, Bessa TA, de Oliveira ML. Human and canine leptospirosis: serological data of Sao Paulo City, Brazil, 2000 to 2003. Rev Cubana Med Trop. 2005;57(1):61-2.

17. Ortega PA, Colín FRF, Gutiérrez BE, Jiménez CM. Frecuency and type of renal lesions in dogs naturally infected with Leptospira species. Ann NY Acad Sci. 2008; 1149:270-4.

18. Meeyam T, Tablerk P, Petchanok B, Pichpol D, Padungtod P. Seroprevalence and risk factors associated with leptospirosis in dogs. Southeast Asian J Trop Med Public Health. 2006;37(1):148-53.

19. Alton GD, Berke O, Reid-Smith R, Ojkic D, Prescott JF. Aumento de la seroprevalencia de leptospirosis y sus factores de riesgo, Ontario 1998-2006. Can J Vet Res. 2009;73(3):167-75.

20. Greenlee JJ, Alt DP, Bolin CA, Zuerner RL, Andreasen CB. Experimental canine leptospirosis caused by Leptospira interrogans serovars pomona and bratislava. Am J Vet Res. 2005;66(10):1816-22.

21. Van de Maele I, Olaus A, Haesebrouck F, Daminet S. Leptospirosis in dogs; a review with emphasis on clinical aspects. Vet Rec. 2008;163(14):409-13. doi: 10.1136/vr.163.14.409.

22. Goldstein RE, Lin RC, Langston CE, Scrivani PV, Erb HN, Barr SC. Influence of infecting serogroup on clinical features of leptospirosis in dogs. J Vet Intern Med. 2006;20(3):489-94. doi: 10.1111/j.1939-1676.2006.tb02886.x. 
23. Barrido EM, Alexanderson E, Halabe CA. Enfermedad de Weil, cinco casos en el Valle de México. Rev Invest Clin (Méx). 1989;41:253-7.

24. Low DG. Leptospirosis canina en: Terapéutica veterinaria. 3 ed. DF (MX): Continental; 1981.

25. Solano-Chinchilla A, Boza-Cordero R, Saenz-Bolaños E. Leptospirosis en humanos. . Rev Cost de Ciencias Médicas. 1996;17(2):41-60.

26. Ellis WA. Leptospirosis as a cause of reproductive failure. Vet Clin North Am Food Anim Pract. 1994;10:463-78.

27. Songer JG, Thiermann AB. Leptospirosis. Zoonosis update. J Am Vet Med Assoc. 1988; 193:1250-4.

28. Spinu I, Topcin V, Trinh Thi Hang Quy, Vo Van Hung, Mguyen Sy Quoe, Long CX, et al. L'homme comme réservoir de virus dans une épidémie de leptospirose survenue dans la jungle. Arch Roum Path Exp. 1963;22:1081-100.

29. Moles CL, Salomón S, Munguía A, editors. Estudio serológico para detectar anticuerpos contra Leptospira interrogans en perros de la ciudad de México. XXI Congreso Nacional de Microbiología; 1990; Villahermosa, Tabasco, México.

30. Flores CR, Solana MP, editors. Problemática de la vacunación contra la leptospirosis canina. XXII Congreso Nacional de AMVEPE 56 63; 1992.

31. García SC, Ibarra ZS. Estudio serológico de Leptospirosis canina en la ciudad de Toluca: Universidad Nacional Autónoma del Estado de México; 1992.

32. Luna AM. Frecuencia serológica de leptospirosis canina en el municipio de Naucalpan de Juárez, Estado de México. Edo. de México (MX): Universidad Nacional Autónoma de México; 1993.

33. Timoney JF, Gillespie JH, Scott FW, Barlough JE. The spirochetes. Hagan \& Bruner's microbiology and infections diseases of domestic animals. 8 ed. Ithaca (US): Comstock Publishing Associates; 1988. p. 45-57.

34. Prescott JF. Leptospirosis. In: Jubb KVF, Kennedy PC, Palmer N, editors. Pathology of domestic animals. (US): Elsevier Academic Press, Inc; 1993. p. 503-11.

35. Ward MP, Glickman LT, Guptill LF. Prevalence of and risk factors for leptospirosis among dogs in the United States and Canada: 677 cases (1970-1998). J Am Vet Med Assoc. 2002;220:53-8.

36. INEGI. Información del estado de Sinaloa. DF (MX): Instituto Nacional de Geografía y Estadística; 1999.

37. Comisión Nacional del Agua. Análisis de las temporadas de huracanes de los años 2009, 2010 y 2011 en México. D F (MX)2012.

38. Fernández C, Obregón A, Rodríguez $G$, editors. Nuevas tecnologías desarrolladas e incorporadas en el diagnóstico de la leptospirosis humana en Cuba. XVIII Congreso Panamericano de Ciencias Veterinarias; 2002; La Habana (CU): Asociación Panamericana de Ciencias Veterinarias.

39. Daniel W. Bioestadística, base para el análisis de las ciencias de la salud. 4th ed. DF (MX): Limusa Willey; 2006.

40. Zavala J, Pinzón J, Flores M, Damián A. La leptospirosis en Yucatán. Estudio serológico en humanos y animales. Rev Salud Púb Méx. 1984;26:254-6.

41. Rivera F, Peña MA, Roa RM, Ordóñez BM. Seroprevalencia de leptospirosis en perros callejeros del norte de la Ciudad de México. Vet Mex. 1999;30(1):105-7.

42. Cárdenas MM, Vado SI, Ortega PA, Rodríguez BJ. Prevalencia de leptospirosis canina en el municipio de Mérida Yucatán. Enfermedades infecciosas y microbiología. 2003;23(3). 
43. Luna AM, Moles CL, Urrutia VR, Torres BJ, editors. Diferencia en la prueba de aglutinación microscópica para el diagnóstico de leptospirosis empleando dos serovariedades del mismo serogrupo. XXVIII Congreso Nacional de Microbiología; 1997; Culiacán, Sinaloa (MX).

44. Pfeiffer DU. Veterinary epidemiology an introduction. London (GB): University of London; 2002.

45. Pita FS, Pertegas DS, Valdez CF. Medidas de frecuencia de enfermedad: Elsevier; 2004 [Available from: www.fisterra.com].

46. Ward MP, Guptill LF, Prahl A, Wu CC. Serovar-specific prevalence and risk factors for leptospirosis among dogs: 90 cases (1997-2002). J Am Vet Med Assoc 2004;224(12):1958-63.

47. Cabezas H, Cabezas O, Bencomo L, Quintana P. Aislamiento de cepa del complejo patógeno Bataviae en paciente vacunado contra copenhageni, canicola y mozdok. Rev Cubana Med Trop. 2005;57(7):73-4.

48. Geisen V, Stengel C, Brem S, Müller W, Greene C, Hertmann K. Canine leptospirosis infections clinical signs and outcome with different suspected Leptospira serogrups (42 cases). J Small Anim Pract. 2007;48(6):324-8. doi: 10.1111/j.1748-5827.2007.00324.x.

49. Luna AM, Moles CL, Gavaldón RD, Nava VC, Salazar GF. La leptospirosis canina y su problemática en México. Rev Salud Anim. 2008;30(1):1-11.

50. Gautam R, Wu CC, Guptill LF, Potter A, Moore GE. Detection of antibodies against Leptospira serovars via microscopic agglutination tests in dogs in the United States, 2000-2007. J Am Vet Med Asosc. 2010;237(3):293-8.

51. Davis MA, Evermann JF, Petersen CR, VancerSchalie J, Besser TE, Huckabee $J$, et al. Serological survey for antibodies to Leptospira in dogs and raccoons in Washington State. Zoonoses Public Health. 2008;55(8):436-42. doi: 10.1111/j.1863-2378.2008.01137.x.

52. González J, Tamayo S, Machado A. Leptospirosis. La Habana (CU): Centro de Información y Documentación Agropecuaria; 1990.

53. Monahan AM, Miller IS, Nally JE. Leptospirosis risks during recreational activities. J Appl Microbiol.2009;107(3):707-16. doi: 10.1111/j.1365-2672.2009.04220.x. 